\title{
GLL
}

$00=0$ Geomatics, Landmanagement and Landscape No. $4 \cdot 2019,73-91$

\section{ANALYSIS OF THE CHANGES TO LAND USE IN SELECTED MUNICIPALITIES OF LUBLIN METROPOLITAN AREA, BASED ON REMOTE SENSING DATA}

\author{
Bogusława Kwoczyńska, Wojciech Sroka, Kamila Sikora
}

\begin{abstract}
Summary
The aim of the study was to diagnose the main trends of the changes in land cover around the urban agglomerations, as illustrated with the example of Lublin, over the last twenty years (1998-2016), as well as their statistical and graphical presentation in the form of digital maps compilation. The project was conducted on the basis of the remote sensing data: RapidEye and LANDSAT 5 TM satellite imagery from three temporal records (1998, 2009-11, 2016-17). Detailed research was carried out in purposefully selected municipalities. The performed analyses showed that in the studied municipalities some changes in the use of arable land and grassland occurred. The largest loss in terms of area share was recorded mainly in the arable land. At the core of the metropolitan area, i.e. in the city of Lublin, over the last 20 years the share of arable land in the total area decreased by almost 11 percentage points (p.p.). In the municipalities located directly at the border with Lublin, this loss was much lower, and was equal 4-5 p.p. Slightly larger changes occurred in municipalities located further from the core, where both in the category of very good and slightly weaker natural conditions, losses of arable land were greater than in municipalities located directly at the core's border of the metropolitan area (MA).
\end{abstract}

\section{Keywords}

satellite imagery $\bullet$ land cover $\bullet$ metropolitan area (MA)

\section{Introduction}

Research studies conducted in many countries of the global north indicate that the greatest dynamics of land use changes occurs in cities and their functional areas [Piorr et al. 2011, Price et al. 2015, Abrantes et al. 2016]. The growing number of urban population and the accompanying processes of urbanization and sub-urbanization contribute to the great qualitative and quantitative changes in land use [Antrop 2004, Lovell 2010, Zasada 2011, Esposito et al. 2018].

Very dynamic changes in land use in metropolitan areas constitute an immense challenge for their management [Mace 2018]. Currently, it is believed that the changes 
taking place in the metropolises and in their neighbourhood should be under the constant monitoring and control. This is related to conducting rational space management in these areas [Hersperger 2018]. One of the ways of conducting the aforementioned monitoring is to determine the changes that have occurred so far in a given area, and to determine the directions that further development may potentially take. The remote sensing data used in this study provide particularly broad possibilities, enabling very precise depiction of the ensuing changes.

In Poland, in the cores of metropolitan areas (MA) the share of agricultural land constitutes over $30 \%$ of their total area, i.e. almost twice as much as built-up and urbanized areas [Sroka et al. 2018]. In the municipalities forming the external zone of the metropolitan area, the percentage of the agricultural land exceeds $60 \%$, i.e. it is more than the national average [Sroka 2018]. Nevertheless, many studies [Lorens and Martyniuk-Pęczek 2010, Krzyk et al. 2013] emphasize that, in the Polish planning practice, peri-urban agricultural land is a reserve for the areas intended mainly for housing construction. In 2010-2014, in Polish metropolitan areas, on average around $0.59 \%$ of arable land was converted to non-agricultural purposes and the dynamics of this process was significantly dependent on the location of land in relation to the core of the metropolitan area [Sroka et al. 2018]. The quoted research [Sroka et al. 2018], but also the study by Busko and Szafranska [2018], disclosed a particularly worrying trend of converting the agricultural land with a very good quality and suitability for agricultural production (land of the I-III classes) to non-agricultural purposes.

The reduction of the surface area of agricultural land in the zones with the high urbanization pressure is often explained with the aid of the concept of economic rents [Diogo et al. 2015]. Alonso [1964], but also much earlier von Thunen and Ricardo emphasized that economic rents determine the use of land [Ustaoglu 2016]. Land is expected to be used for the purpose which brings the greatest utility, taking into account the relative benefits of alternative land uses [Diogo et al. 2015]. The effect of this mechanism in practice is the reduction in the share of the relatively low profitable agricultural land [Mazzocchi et al. 2013] for the benefit of other, more profitable ways of using the land. Thus, in the areas that are located closer to cities (experiencing greater pressure from the more profitable non-agricultural sector), conversion of the land to non-agricultural purposes is more likely. Similarly, the lower the usefulness of agricultural production space, and thus its profitability, the higher the probability of agricultural land conversion [Diogo et al. 2015].

The aim of the study was to diagnose the main trends of land cover changes around the urban agglomeration, with particular reference to the arable land and grassland. The analyses were conducted using the cases of the selected municipalities of the Lublin metropolitan area during the last twenty years (1998-2016).

The results of the research were presented using the graphical (compilation of digital maps), tabular (statistical statements), and descriptive methods. The project was implemented on the basis of remote sensing data: the satellite imagery RapidEye and LANDSAT TM. 


\section{Photogrammetry and satellite remote sensing as tools for the analysis of land use changes}

Monitoring of the changes has become possible with the development of the photogrammetry and satellite remote sensing. The development of remote sensing techniques, in particular the increase in the temporal and spatial resolution of remote sensing images, made it possible both to perform detailed studies of small areas, and to create global studies of changes in land cover and land use. In places where these changes occur very quickly, they can be observed in real time [Verburg et al. 2009].

In remote sensing studies, land cover is observed, and on its basis, conclusions concerning land use are drawn. Therefore, keys to the classification are constructed, in which specific divisions fit both concepts, defining in a given class a specific type of land cover corresponding to its use. Keys of this type are widely used in research dealing with the subject matter of Land Use/Land Cover [Civco et al. 2002, Chen et al. 2003, Cakir et al. 2006].

The changes occurring in the studied area can be observed and analysed on the basis of generally available satellite systems, either free-of-charge (for example SENTINEL-2A, ESA, LANDSAT) or commercial (for example WorldView-2, DigitalGlobe, RapidEye). These systems carry out continuous observations of the Earth's surface, obtaining images with high spatial and spectral resolution, enabling the development of current maps of Land Use and Land Cover ( LULC) [Wężyk et al. 2016].

A comprehensive review of the methods for detecting changes on the basis of satellite imagery has been made by Lu et al. [2004]. The authors divided the methods into seven general groups: algebraic methods, transformations, classifications, models, application of geographic information systems, visual analysis, and other approaches.

Among the listed methods there is the classification method applied in this study. The most popular method is the so-called post-classification analysis. It consists in comparing two independent classifications, performed on two images of the same area. This method was used, among others, by Kwoczyńska et al. [2018], Civco et al. [2002] - unsupervised classification of land cover by the ISODATA method, using images from the Landsat; Bauer et al. [2003] - study of changes in land cover in the metropolitan area of Minneapolis and St. Paul based on data from the Landsat, comparison of own, complex classification methods; Michałowska and Głowienka-Mikrut [2010] - the study of land cover changes in the area of the Słowiński National Park using the largest likelihood classification, carried out using images from the Landsat satellites; Prakasam [2010] - supervised classification of land cover with images from the TM sensor. Bochenek [2004] prefers the comparison of two independent classifications, comparing the accuracy of this method with the methods of comparing the spectral reflection values from two registration dates, comparison of the values of green indicators, analysis of the main components, analysis of changes' vector, classification of linked images [Niedzielko and Lewiński 2012]. 


\section{Methodological assumptions}

\subsection{Source data}

Satellite data is a particularly important source of information about the geographical environment and, consequently, also about its changes. When examining changes in land cover, the most important advantages of satellite images are: synopticity, high repeatability of imaging of the same areas, relatively low cost of acquisition, and automation of the processes of interpreting their content [Ciołkosz and Poławski 2006]. Availability is an important factor when using this type of data. The Landsat mission has been providing data about the Earth for forty years. All archival and current images are available to any user worldwide, free of charge. Thematic Mapper and Enhanced Thematic Mapper + sensors placed on satellites moving on the Helio-synchronous orbit are the sources of multispectral images with terrain resolution of $30 \mathrm{~m}$.

In this research, the source materials subdivided into three periods were used, i.e. set A: covering the LANDSAT 5 TM (Thematic Mapper, NASA) satellite scenes from 1998, set B: the RapidEye images from 2009-2011, and set C: the RapidEye images from 2016-2017.

The LANDSAT TM data were chosen due to their 40-year uninterrupted sequence of observations and general availability [Loveland and Dwyer 2012, Markham and Helder 2012, Wulder et al. 2012]. Five basic criteria were adopted in the selection of imagery, i.e.: registration period in April-August (sets A, B and C); the cloudiness of a single scene no more than $20 \%$; terrain resolution less than $30.0 \mathrm{~m}$; radiometric resolution of 8 bit; spectral resolution of minimum 4 channels [Wężyk et al. 2013]. The time criterion - obtaining imagery from April to August - was dictated by the best quality of satellite imagery for the examined period of the studies.

The sets B and C (2009-2011 and 2016-2017) included multi-spectral satellite imagery of the RapidEye system, which is obtained via a constellation of five satellites, placed on a Helio-synchronous orbit at 19-minute intervals, imaging in 5 spectral channels $(\mathrm{RGB}+2 \times \mathrm{NIR})$ with a spatial resolution of $5.0 \mathrm{~m}$ [Krischke et al. 2000, Sandau et al. 2010]. These images were obtained for the purposes of the project 2016/21/D/ HS4/00264 entitled: Urban agriculture as a challenge for the sustainable development of metropolitan areas in Poland - economic and social, environmental and planning aspects. The time span (2009-2011 and 2016-2017) resulted from the selection of satellite images with the lowest degree of cloud coverage for the examined area. They were used to classify the land cover and the land use (LULC, Land Use/Land Cover) of Lublin and the municipalities adjacent to it with the timeliness for 2016. Digital orthophotomaps with a spatial resolution of $0.25 \mathrm{~m}$ and timeliness for 2016 were also acquired for the study area. The orthophotomaps were used to improve the quality of the RapidEye satellite image classification (years 2009-2011 and 2016).

\subsection{Characteristics of the examined objects}

Selected municipalities of the Lublin metropolitan area were included in the analysis. It is one of the smallest Polish metropolitan areas - the only one located in the eastern part 
of Poland (east of the Vistula River). The choice of this metropolitan centre was dictated by the relatively high importance of agriculture in the region's economy and a very large percentage of agricultural land, which is characterized by the very favourable natural conditions for agricultural production (the best natural conditions among all Polish metropolitan areas). At the same time, the metropolitan area of Lublin belongs among the least economically developed (relatively high unemployment, low entrepreneurship, etc.), and it is characterized by the relatively unfavourable demographic conditions as compared to other Polish metropolitan areas [Statistical Office 2015].

The detailed analysis covered the city of Lublin (core of the metropolitan area) together with four municipalities selected in a targeted manner (Fig. 1). When selecting the municipalities, their location in relation to the MA core was taken into consideration (municipalities bordering with the core vs. municipalities located on the outskirts of MA) as well as the quality of natural conditions of agricultural production (better vs. worse natural conditions of agricultural production) (Table 1).

The city of Lublin, i.e. the core of the metropolitan area, is one of the smallest Polish metropolitan centres, which is associated with its relatively small impact on the surrounding municipalities. Nevertheless, it is the ninth city in the country in terms of the number of inhabitants and also the largest urban centre in eastern Poland. Lublin together with the surrounding areas acts as the main centre of economic life, with the significant concentration of various types of business entities and business-related institutions and services [Kociuba 2011]. In the city, the agricultural land is of the great importance (over $50 \%$ of the total area), and it also enjoys very favourable - indeed some of the best - natural conditions in Poland for agricultural production [Witek 1994].

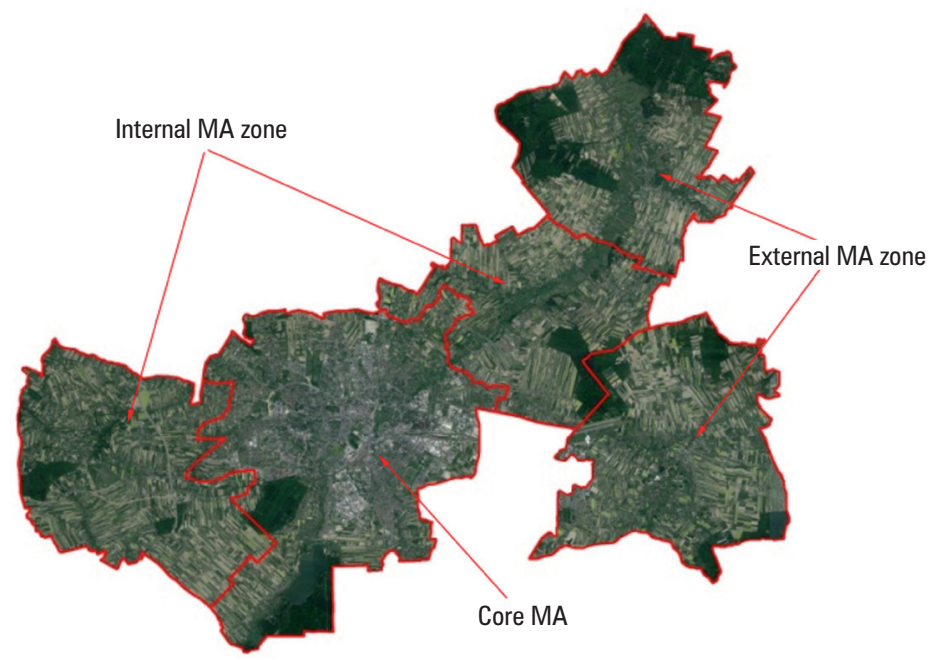

Source: Authors' own study with the use of the orthophotomap from the Geoportal

Fig. 1. The area of the five studied municipalities of the Lublin metropolitan zone 


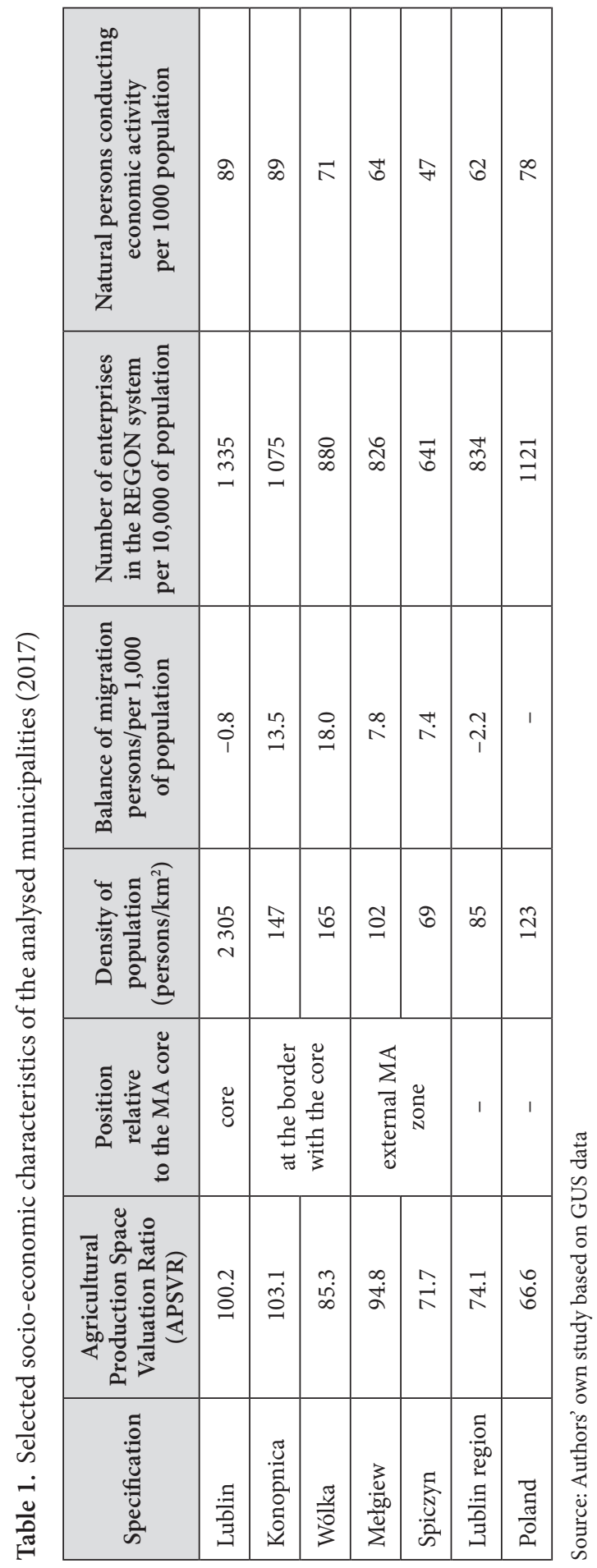


The two analysed municipalities are located near the border with the core of the metropolitan area. Konopnica municipality (district of Lublin) is characterized by very favourable natural conditions for agricultural activity, whereas the Wólka municipality (district of Lublin) has slightly worse conditions. These are typical peri-urban municipalities, characterized by good demographic conditions (relatively high population density and positive migration balance), coupled with also good economic conditions (relatively high entrepreneurship rates and low unemployment). Although agricultural lands occupy over $80 \%$ of the total area in both municipalities, and a large part of the population still makes the living from farming, agriculture is not perceived in their area as an important economic sector [SRGK 2016, SRGW 2009]. The opportunities for the development of the municipalities are seen in the expansion of the metropolitan functions of Lublin and the progressing suburbanization (attracting those more prosperous residents of Lublin city).

Two municipalities located further away from the MA core (over $20 \mathrm{~km}$ ) were also taken into consideration in the analysis, including the municipality of Mełgiew (district of Świdnica) characterized by relatively good natural conditions of agricultural production, and the municipality of Spiczyn (district of Łęczna) with worse natural conditions. Both municipalities - both in the context of the Lublin region and of the country as a whole - are characterized by relatively poor demographic and economic conditions, which illustrates the relatively weak impact of the city of Lublin. In the first of the analysed municipalities (Mełgiew), agriculture and arable land constitute an important element of space (arable lands occupy over $91 \%$ of the municipality's area) as well as of the municipality's economy (a large number of people living primarily off agriculture), and the municipality's authorities perceive it as one of the priorities of the municipal development [SRGM 2016]. In the Spiczyn municipality, the arable land constitutes about $66 \%$ of the area, and agriculture is characterized by worse natural and structural conditions. Moreover, agricultural character of the municipality is perceived as a limitation to its development (bringing low income to the municipal budget).

\subsection{Process of remote sensing images processing}

The work on the multi-scale, multispectral and multi-temporal remote sensing data required their appropriate adjustment in terms of resolution and geometry. Before the classification, the LANDSAT 5 TM satellite imagery were processed in order to generate derivative layers, such as: the Principal Component Analysis - PCA, operations on the edge filters (e.g. the Laplace filter), indices (e.g. the Normalized Difference Vegetation Index - NDVI, channels ratio - SR or Simple Ratio, and EVI or Enhanced Vegetation Index), which was necessary to increase the accuracy of the classification [Wężyk et al. 2013]. On the basis of the acquired images, the coloured compositions the digital classification have been developed and subjected to digital classification. The three-colour compositions were created for LANDSAT imaging: (4)(2)(1) (Fig. 2a), (5)(3)(4) (Fig. 2b) and (1)(4)(5) (Fig. 2c). The third composition from channels 1, 4, and 5 was selected for the analysis, because it mapped individual usable structures in the best way. 

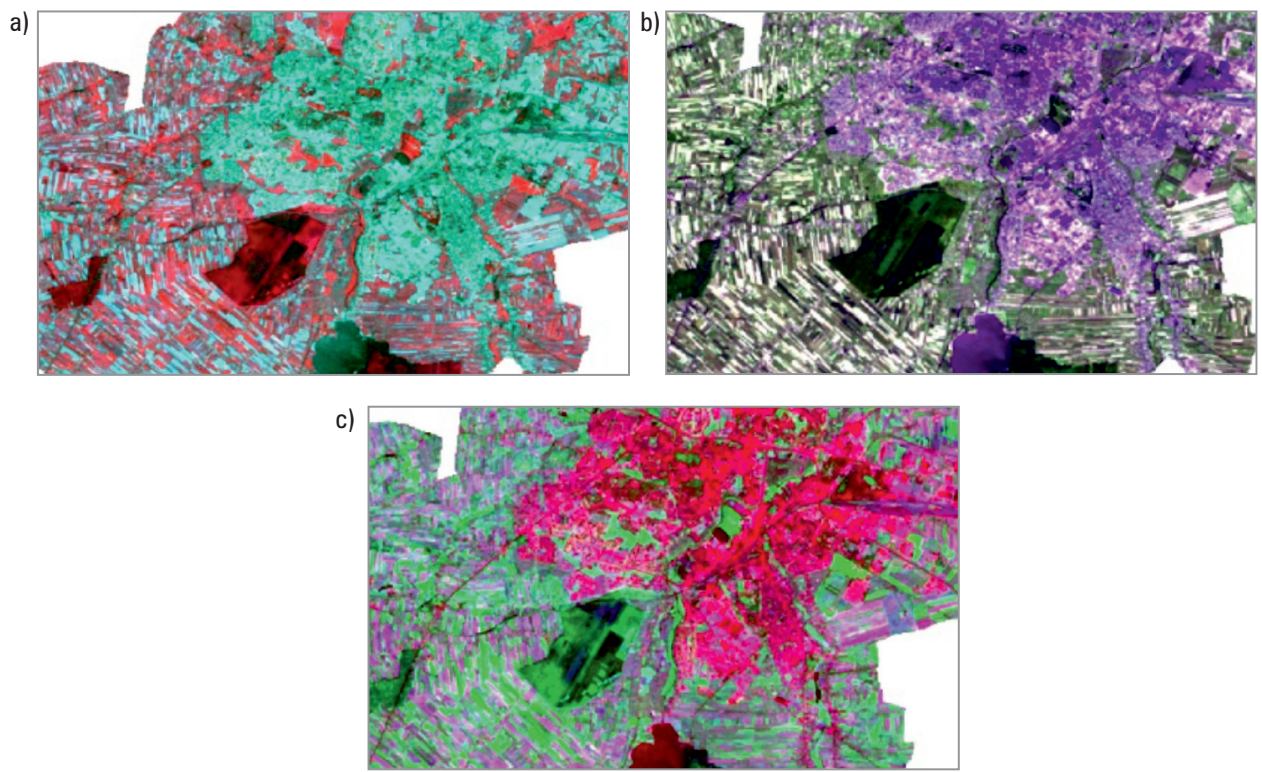

Source: Authors' own study based on photogrammetric data in the SAGA GIS 4.0.1 program

Fig. 2. The colour compositions created from the Landsat 5 images from the following channels: a. $(4)(2)(1)$, b. (5)(3)(4), c. (1)(4)(5)

For the RapidEye imaging, colour compositions were made on the basis of the following channels: (2)(4)(5) (Fig. 3a), (3)(1)(5) (Fig. 3b), (5)(4)(2) (Fig. 3c) and (4) $(1)(2)$ (Fig. 3d) from which the second composition $(3)(1)(5)$ was considered for classification.

The SAGA GIS software was used for the comprehensive analysis presented in the paper. The entire project was conducted using a supervised classification in accordance with the "Maximum Likelihood" technique (Fig. 4).

The supervised classification is one of the most commonly used methods of digital classification. It is a pixel classification (similar to an unsupervised classification), in which pixels are assigned the appropriate classes on the basis of the analysis of reflections, registered in particular spectral ranges [Bałazy et al. 2013].

In this method, the computer operator extracts objects on the basis of the determined statistical parameters (for individual so-called training fields). This means that each part of the picture has a defined land cover class. In order to do that, it is necessary to specify the pixels that will visualize the image during the classification. Each pixel then represents the land object assigned to it, and is a spectral pattern. The accuracy of this systematization depends on the proper selection of training fields [Adamczyk et al. 2010].

The "Maximum Likelihood" method is a technique based on the probability that a pixel belongs to a particular class. The basic equation assumes that these probabilities are equal for all classes, and that the starting bands have a normal distribution. Each 
a)
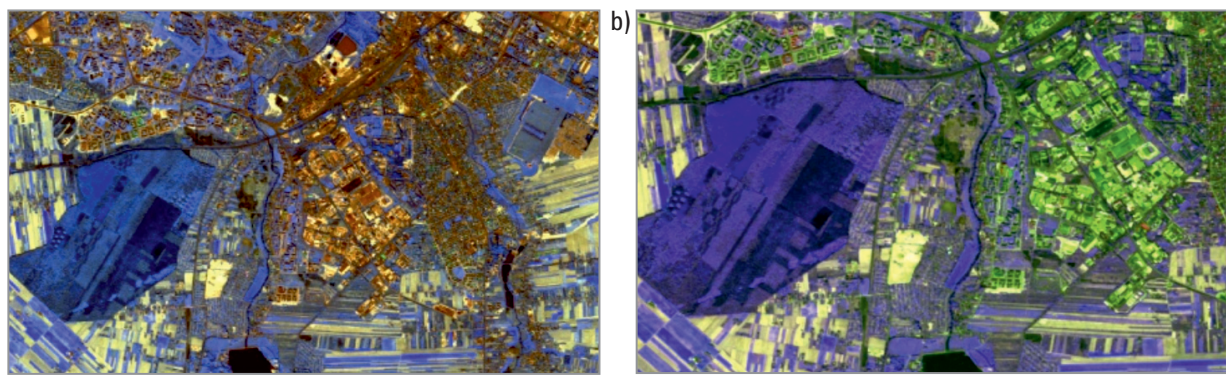

c)
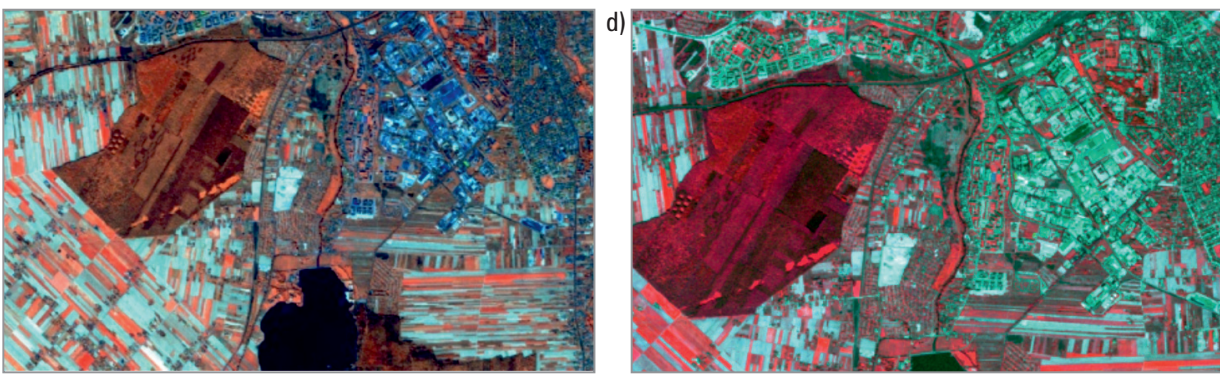

Source: Authors' own study based on photogrammetric data in the SAGA GIS 4.0.1 program

Fig. 3. Colour compositions created from RapidEye imaging from the following channels: a. (2) $(4)(5)$, b. (3)(1)(5), c. (3)(1)(5), d. (4)(1)(2)

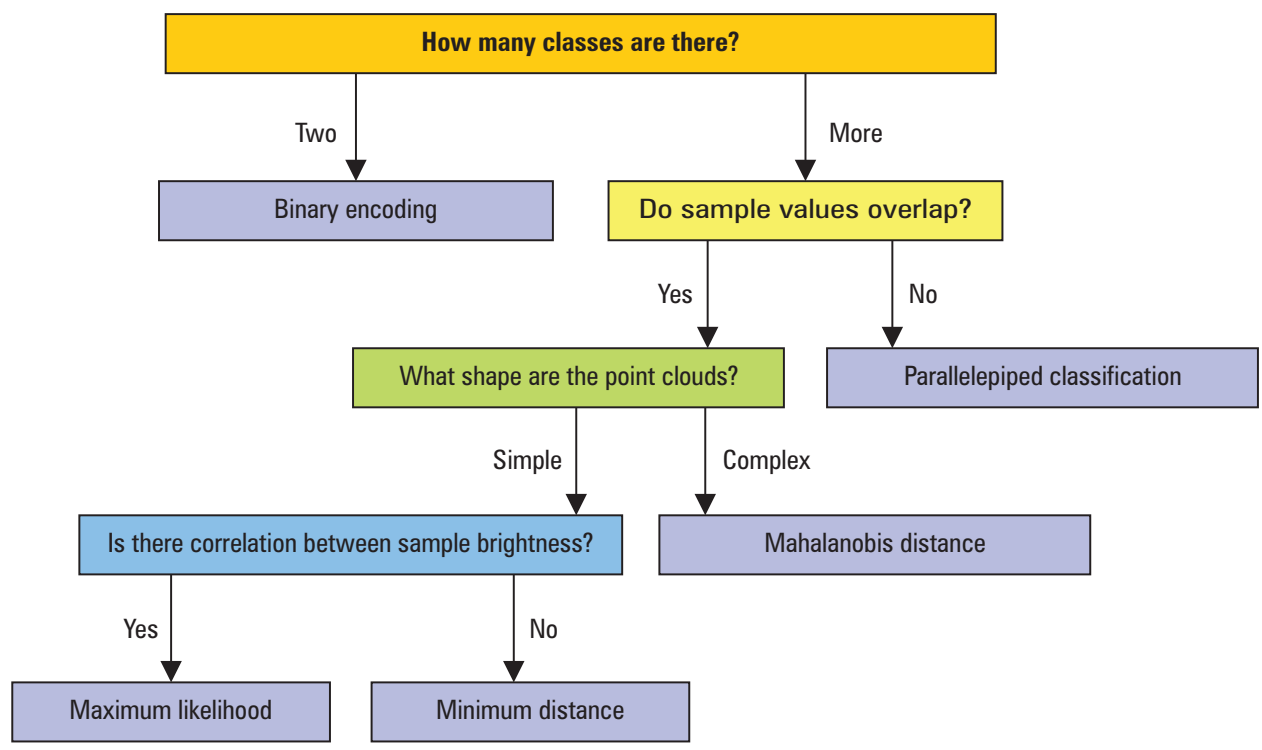

Source: http://www.50northspatial.org/pick-best-supervised-classification-method/

Fig. 4. Diagram showing the method of choosing the technique for supervised classification 
pixel is qualified to a specific group on the basis of the calculated mean value for the class [Oliveira Duarte et al. 2016]. Li and Yeh following [Lu et al. 2004] applied the highest probability supervised classification to detecting changes in the land cover in the Pearl River Delta area in China. It was this technique that was also selected for the classification of the discussed research area.

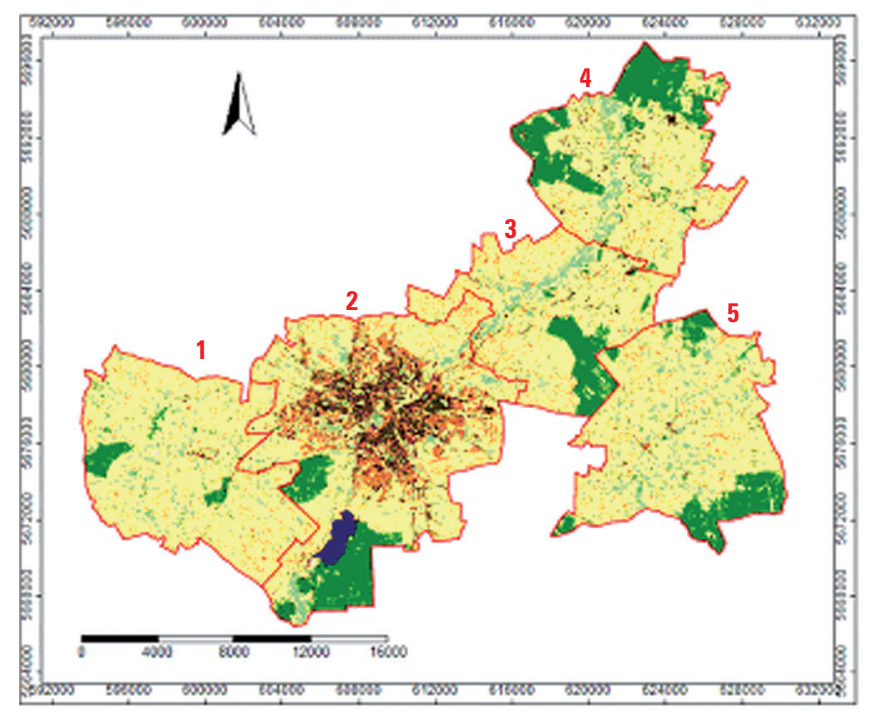

The Legend for communes

1 - Konopnica

2 - Lublin

3 - Wólka

4 - Spiczyn

5- Małgiew

The Legend for classes

— Water

2 Forest

$\square 3$ Grassland

$\square$ Scattered settlement

5 Compact settlement

$\square 6$ Arable land

7 Wasteland

Source: Authors' own study

Fig. 5. The land use map prepared on the basis of the LANDSAT 5 views from 1998 against the background of the discussed municipalities

a)

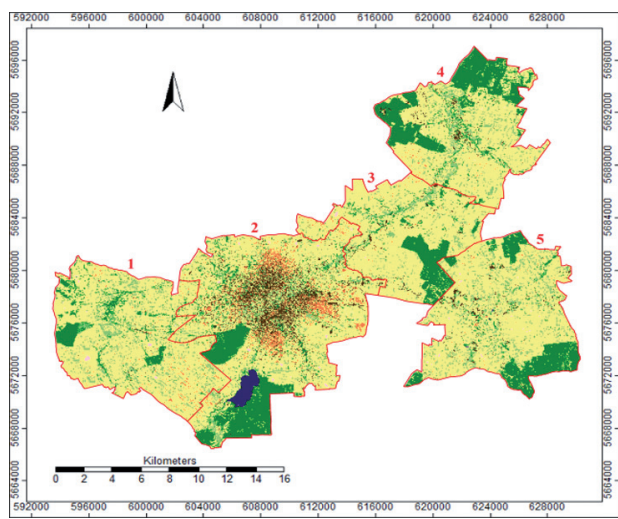

b)

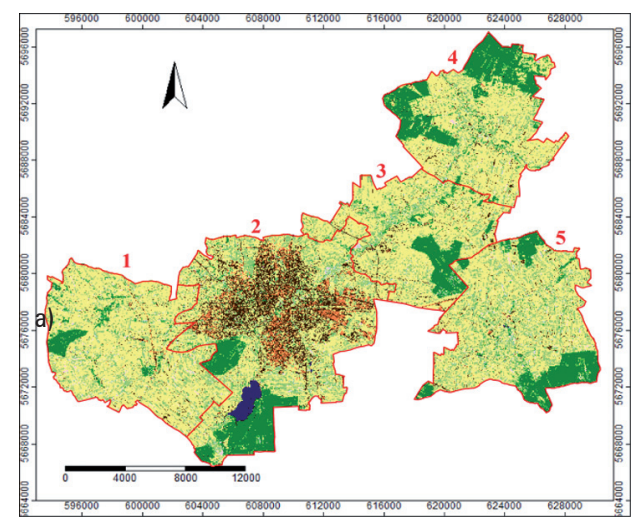

Source: Authors' own study

Fig. 6. The land use map prepared on the basis of RapidEye images from the period: a. 20092011, b. 2016-2017 against the background of the discussed municipalities 
While selecting the training fields reflecting particular classes, special attention was paid to the accuracy in the selection of pixels. As a result of the classification, 7 classes of land cover and land use were obtained for three research dates (1998, 2009-2011, and 2016-2017), i.e.: arable land, grassland, urbanized areas (compact settlement and scattered settlement), water, forests, and wasteland. The quality control of the supervised classification showed the accuracy at the level of $87.7 \%$ for the LANDSAT 5 TM analyses of scenes, and at the level of $90.9 \%$ for the RapidEye imagery. The Kappa coefficients for the subject classification were 0.83 (LANDSAT TM) and 0.88 (RapidEye), respectively. The effect of the study presents maps of land cover for individual research dates (Fig. 5 and 6).

\section{Research results and discussion}

The basic assumption in the adopted method of the study of changes was to carry out independent satellite image classifications for each registration date, using the same set of land cover classes and comparison of classification images. The accuracy of identification of the individual land cover classes directly affects the precision of determining the change areas. Therefore, it is extremely important to use such method of classification that would ensure the classification of the satellite image with the highest possible accuracy. In the present study, it was the maximum likelihood method.

Comparison of the resulting land use maps of the studied areas for individual time periods made it possible to determine changes in land use structure both in the city of Lublin and in neighbouring municipalities over 20 years. The detailed list of areas and changes for the adopted classes of land is included in Table 2.

The percentage changes of individual agricultural areas in comparison to the previously considered period of the study are marked in red in Table 2 . The performed analyses showed that in the analysed municipalities the changes in the way of using of the arable land and grassland occurred. Definitely the largest area loss was recorded in the arable land category. In the core of the metropolitan area, i.e. in Lublin, over the last 20 years, the share of arable land in the total area decreased by almost 11 percentage points (p.p.). In municipalities located directly at the border with Lublin, this loss was already much lower, equal to 4.14 p.p. in the case of Konopnica, and 5.33 p.p. for Wólka municipality. Slightly larger changes occurred in municipalities located further from the MA core, that is in the municipalities of Spiczyn and Mełgiew, where, both in very good and slightly weaker natural conditions, the losses of arable land were greater than in municipalities located directly at the border of the MA core. The changes that take place in selected municipalities of the Lublin MA allow us to reject the hypothesis that close proximity to the MA core will result in a higher decrease in the share of arable land.

When analysing the importance of natural conditions in the processes of land use changes, a large loss of arable land was noted in municipalities with worse natural conditions, i.e. in Wólka (-5.3 pp) and Spiczyn (-7.2 pp), and slightly smaller changes were recorded in the municipalities of Mełgiew and Konopnica (Fig. 7). This dependency is consistent with the operation of the economic rents law (differential rent I). 


\begin{tabular}{|c|c|c|c|c|c|c|c|c|c|c|c|c|c|c|c|c|c|}
\hline \multirow{11}{*}{ 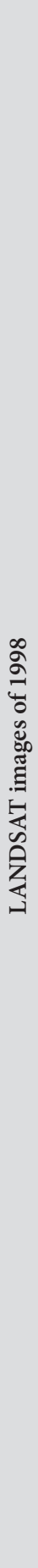 } & \multirow{10}{*}{ 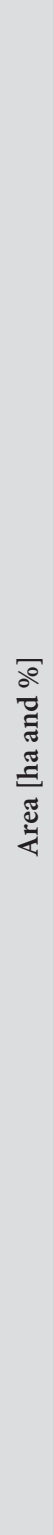 } & \multirow{2}{*}{ हैํํㄹ } & 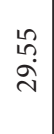 & $\stackrel{8}{\circ}$ & $\begin{array}{l}\stackrel{2}{1} \\
i n\end{array}$ & $\begin{array}{l}\infty \\
i \\
i\end{array}$ & Бे & $\mid \begin{array}{l}\tilde{o} \\
\infty \\
\infty\end{array}$ & 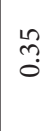 & & \multirow{2}{*}{\multicolumn{2}{|c|}{ क्र }} & 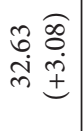 & $\stackrel{8}{\circ}$ & $\begin{array}{l}m \\
\infty \\
\dot{\vec{q}} \\
\dot{p}\end{array}$ & $\begin{array}{l}+\widehat{T} \\
\stackrel{2}{i} \\
\stackrel{0}{1}\end{array}$ & 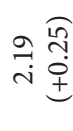 \\
\hline & & & $\begin{array}{l}\overrightarrow{0} \\
\stackrel{\circ}{\circ} \\
\stackrel{\circ}{0}\end{array}$ & $\stackrel{\circ}{\circ}$ & 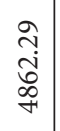 & $\begin{array}{l}\stackrel{N}{N} \\
\stackrel{\sim}{\sim} \\
\text { J }\end{array}$ & $\begin{array}{l}\vec{b} \\
+\overrightarrow{0} \\
\stackrel{-}{0}\end{array}$ & $\begin{array}{c}\curvearrowright \\
\dot{\vec{j}} \\
\infty \\
0\end{array}$ & 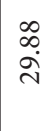 & ஸे & & & $\begin{array}{l}\stackrel{0}{+} \\
\stackrel{2}{\stackrel{N}{N}} \\
\text { N }\end{array}$ & $\stackrel{\circ}{\circ}$ & 官 & $\begin{array}{l}\stackrel{8}{\mathrm{i}} \\
\text { సે }\end{array}$ & $\begin{array}{l}\sigma \\
0 \\
\dot{0} \\
\infty \\
-1\end{array}$ \\
\hline & & 3 & $\begin{array}{c}\overrightarrow{0} \\
\stackrel{0}{c}\end{array}$ & $\stackrel{8}{\circ}$ & $\underset{i}{F}$ & 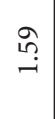 & $\stackrel{?}{i}$ & 吕 & $\overrightarrow{\widetilde{\sigma}}$ & & & 3 & 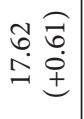 & $\stackrel{8}{\circ}$ & $\begin{array}{l}\hat{f} \\
\hat{f} \\
\infty \\
\infty \\
0\end{array}$ & 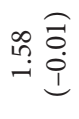 & 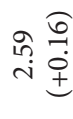 \\
\hline & & $\sum_{\Sigma}^{\Xi}$ & $\begin{array}{l}+1 \\
\infty \\
\infty \\
-0 \\
-1\end{array}$ & $\stackrel{8}{\circ}$ & 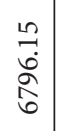 & 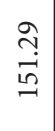 & $\begin{array}{l}b \\
\stackrel{0}{0} \\
\vec{\lambda}\end{array}$ & $\begin{array}{l}\tilde{\sigma} \\
\infty \\
\dot{\sigma} \\
\sigma\end{array} \mid$ & $\begin{array}{l}\hat{0} \\
\text { ¿ें }\end{array}$ & $\frac{n}{n}$ & & $\sum^{ \pm}$ & 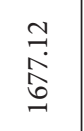 & $\stackrel{8}{\circ}$ & 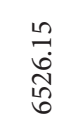 & $\begin{array}{l}\infty \\
0 \\
0 \\
0\end{array}$ & $\begin{array}{l}\text { กิ } \\
\text { ஸे } \\
\text { ปู }\end{array}$ \\
\hline & & $\Im$ & 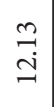 & $\stackrel{8}{\circ}$ & 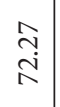 & $\stackrel{\substack{n \\
i}}{i}$ & $\stackrel{n}{\dot{m}}$ & $\overrightarrow{0}$ & $\stackrel{\infty}{\stackrel{0}{0}}$ & & & & 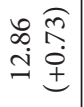 & $\begin{array}{l}8 \\
0 \\
0\end{array}$ & 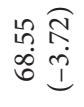 & 范 & 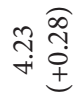 \\
\hline & & 3 & $\begin{array}{l}\tilde{n} \\
\tilde{\sigma} \\
\stackrel{\infty}{\infty} \\
\end{array}$ & $\stackrel{\widehat{\jmath}}{0}$ & 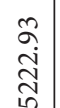 & 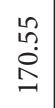 & $\begin{array}{l}\text { ڤ్ } \\
i \\
\infty \\
\infty \\
\sim\end{array}$ & 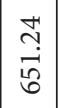 & $\stackrel{\stackrel{\sim}{n}}{\tilde{N}}$ & 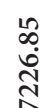 & 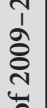 & 3 & $\begin{array}{l}\stackrel{\sim}{+} \\
\text { న̆ }\end{array}$ & $\stackrel{\infty}{\stackrel{\infty}{0}}$ & $\begin{array}{l}\infty \\
\infty \\
\stackrel{\infty}{2} \\
2\end{array}$ & $\begin{array}{l}n \\
\text { an } \\
\stackrel{\sigma}{0}\end{array}$ & $\begin{array}{l}\stackrel{n}{n} \\
\dot{n} \\
\dot{n}\end{array}$ \\
\hline & & $\stackrel{\mathscr{J}}{\mathscr{J}}$ & $\stackrel{\vec{F}}{+}$ & $\stackrel{8}{\circ}$ & $\begin{array}{l}0 \\
0 \\
\dot{b} \\
\infty\end{array}$ & $\stackrel{\bullet}{\stackrel{-}{-}}$ & $\begin{array}{l}\infty \\
\stackrel{\infty}{0} \\
i\end{array}$ & $\mid$\begin{tabular}{c}
\multirow{N}{*}{} \\
in
\end{tabular} & $\stackrel{5}{0}$ & & 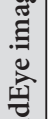 & .ֶّ & 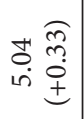 & $\stackrel{8}{\circ}$ & 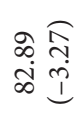 & 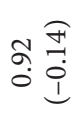 & 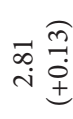 \\
\hline & & పే & 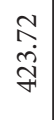 & $\stackrel{8}{\circ}$ & $\begin{array}{l}\vec{n} \\
\dot{0} \\
\stackrel{n}{N} \\
\stackrel{n}{n}\end{array}$ & 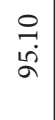 & $\stackrel{\infty}{\stackrel{\infty}{\sharp}}$ & $\begin{array}{c}\infty \\
\stackrel{2}{\rightarrow} \\
\text { F } \\
\end{array}$ & $\begin{array}{l}0 \\
\stackrel{0}{n} \\
-1\end{array}$ & 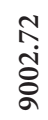 & & శే & $\begin{array}{l}\infty \\
\stackrel{n}{n} \\
\ddot{q}\end{array}$ & $\stackrel{8}{\circ}$ & 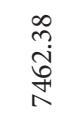 & $\begin{array}{l}0 \\
\infty \\
i \\
\infty\end{array}$ & $\stackrel{\stackrel{9}{\vec{n}}}{\stackrel{\vec{n}}{N}}$ \\
\hline & &.$\Xi$ & 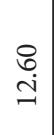 & $\stackrel{\infty}{\infty}$ & $\begin{array}{l}\mathfrak{r} \\
\dot{i n} \\
\text {. }\end{array}$ & $\begin{array}{l}\infty \\
\stackrel{+}{+} \\
\underset{-}{+}\end{array}$ & $\begin{array}{l}\text { हे } \\
\text { से }\end{array}$ & $\begin{array}{l}\vec{\sigma} \\
+\end{array}$ & $\stackrel{10}{0}$ & & & & $\begin{array}{ll} & \widehat{E} \\
0 & 0 \\
& 0 \\
& \pm\end{array}$ & $\begin{array}{l}\widehat{\Xi} \\
0 \\
0 \\
+ \\
\infty \\
\infty \\
\infty\end{array}$ & 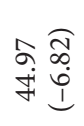 & 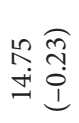 & 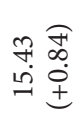 \\
\hline & & - & $\begin{array}{l}\hat{\infty} \\
\dot{0} \\
\infty \\
\infty \\
-1\end{array}$ & $\begin{array}{l}\bar{\sigma} \\
\infty \\
\curvearrowright\end{array}$ & 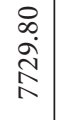 & 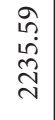 & $\begin{array}{l}\infty \\
\infty \\
\stackrel{\infty}{人} \\
\stackrel{N}{N}\end{array}$ & $\begin{array}{l}\infty \\
\infty \\
\infty \\
\infty \\
\hat{n}\end{array}$ & $\begin{array}{l}0 \\
\text { in } \\
\text { in }\end{array}$ & F্ন & & এ & 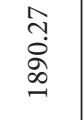 & 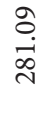 & 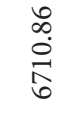 & 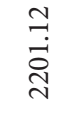 & 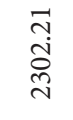 \\
\hline & 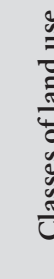 & 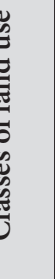 & $\begin{array}{l}\overrightarrow{0} \\
\stackrel{0}{0} \\
\dot{0}\end{array}$ & $\frac{\overrightarrow{ \pm}}{3}$ & 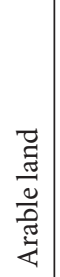 & 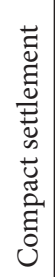 & 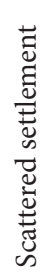 & 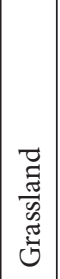 & 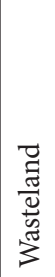 & స్ & & 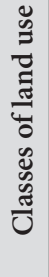 & 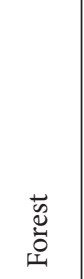 & 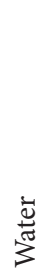 & 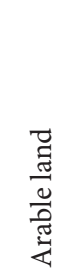 & 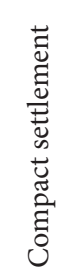 & 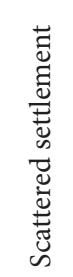 \\
\hline
\end{tabular}




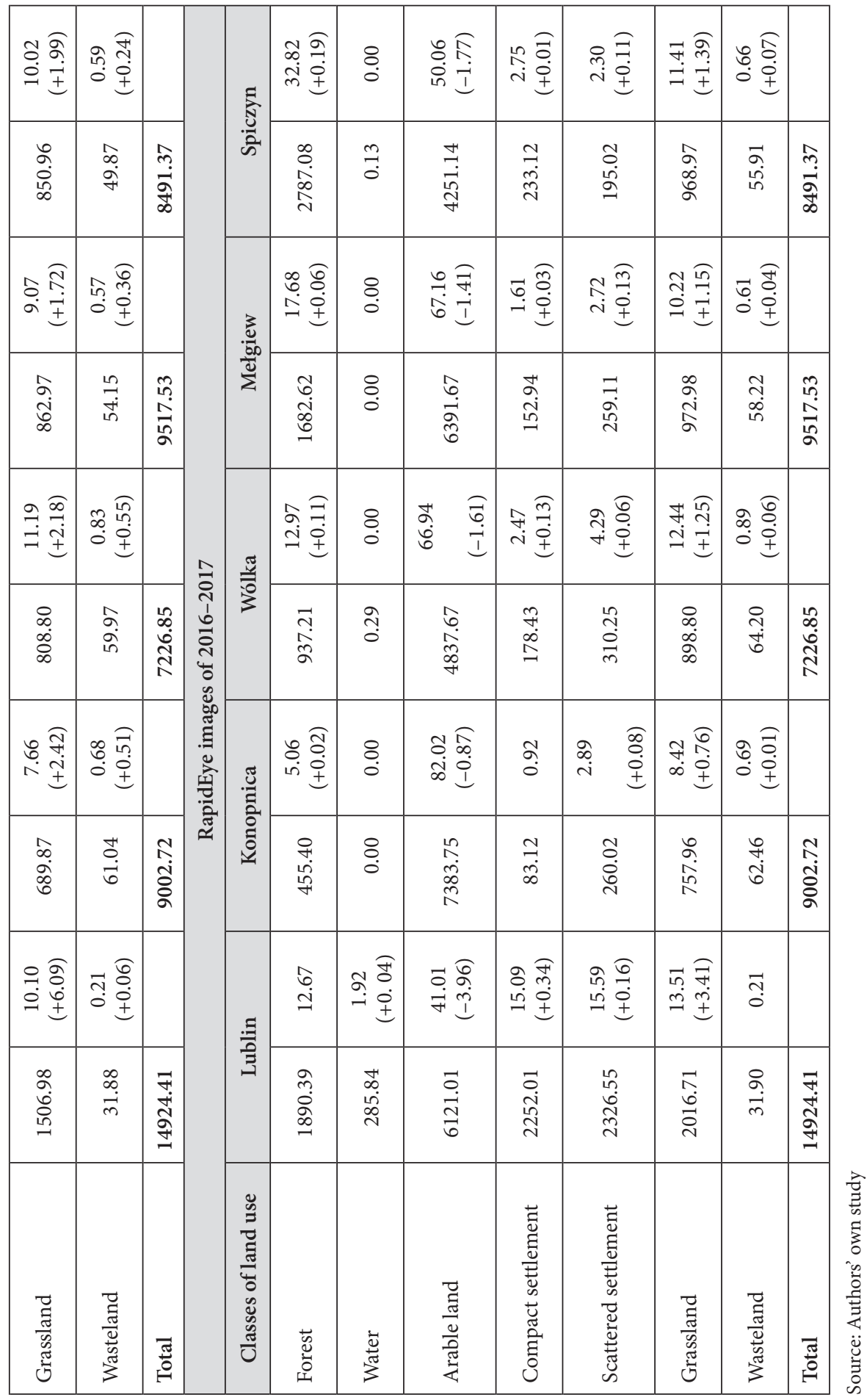


It is also emphasized in the subject literature that land with lower agricultural production suitability is the first to be excluded from agricultural use [Gellrich and Zimmermann 2007, Xie et al. 2014, Wojewodzic 2017].

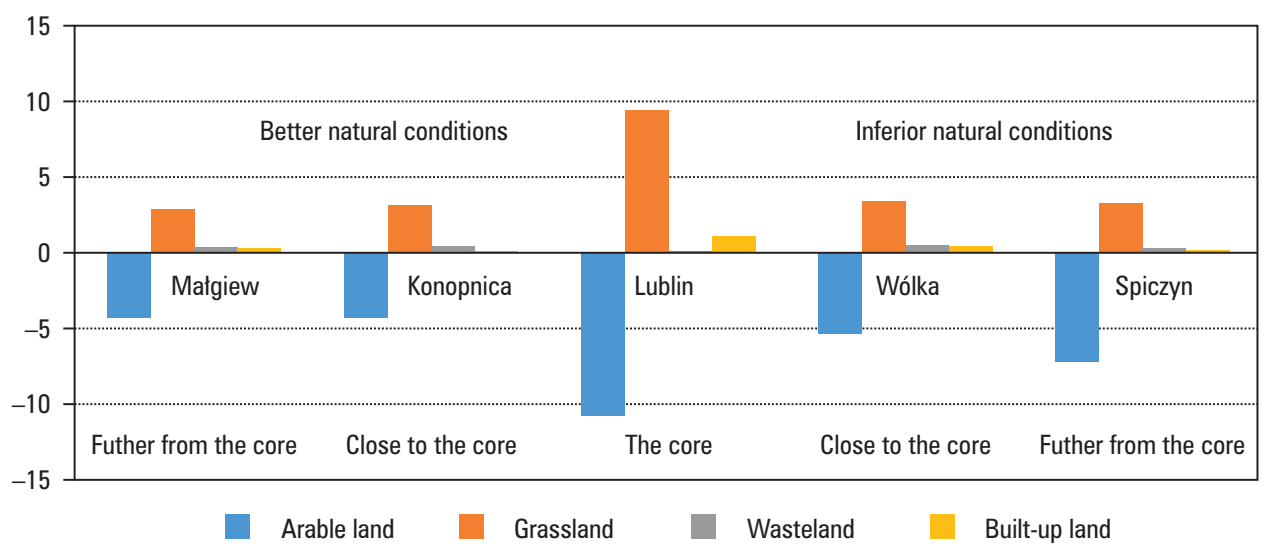

Source: Authors' own study

Fig. 7. Changes in the area of selected classes in the years 1998-2016/17 for the analysed municipalities (percentage points)

The research also showed very large changes in the share of grasslands, where they were strongly correlated with the changes in arable land. The increase of the area of grasslands was achieved at the expense of arable land, because apart from Lublin (increase of built-up areas by $1.1 \mathrm{pp}$.) and Spiczyn (increase of forest area by $3.3 \mathrm{pp}$.), there were no changes greater than 1 percentage point in land uses other than arable land and grassland. In the analysed municipalities, no changes were noted in the percentage of parks, green areas and estate green areas in the total area [GUS 2017]. It should therefore be inferred that, with a growing share of grasslands and decreasing livestock density, the users of arable lands decided to extensify agricultural production. Across the whole study area, more intensive production on arable land was transformed into a less intensive one, based on the use of grassland. Other researchers [for example Wojewodzic 2012, Wästfelt and Zhang 2016, Pölling et al. 2017] point out that in areas with a relatively attractive labour market (for instance, peri-urban municipalities), some farm owners, and especially part-time farmers, abandon agricultural activity and undertake work outside agriculture.

The observed trends are contrary to the operation of "classic" economic rents, because the land is not converted to other more profitable uses. What factors, therefore, prompt land users to act in a seemingly non-rational way? The answer to this question is provided by the new institutional economy and the theory of rent seeking [Musiał and Wojewodzic 2014, Satoła et al. 2018]. Users of agricultural land (also grassland), in addition to income from production activities, may also achieve other economic rents, 
including the institutional rent (payments under the CAP, the use of insurance benefits), the planning rent (re-qualification of agricultural land for construction areas), and the location rents (higher prices for conveniently located land). Speculative activities are also of great importance. While conducting research on the problem of abandoning the use of agricultural land, Sroka and others [Sroka et al. 2017] note that some owners of agricultural land do not sell or lease their land, expecting a better offer to sell the plot, and an increase of its value in the future. Thus, the extensification of agricultural activity may be beneficial to the land user.

In the analysed municipalities there were relatively small increases in the area of built-up land, because only in Lublin they increased by 1.1 percentage points. In contrary to the hypotheses made and research conducted by other scholars [e.g. Sroka 2018], Lublin as a regional development centre does not contribute to the conversion of agricultural land for the development purposes in neighbouring municipalities. However, it affects the reduction of the intensity of agricultural production, a phenomenon, which - in the opinion of many scholars [Queiroz et al. 2014, Terres et al. 2015, Leal Filho et al. 2017] - is unfavourable.

\section{Summary and conclusions}

The aim of the present study was to diagnose the main trends in land cover changes, in the selected municipalities of the metropolitan area of Lublin. The analyses were focused mainly on the assessment of changes in the share of arable land and grassland. The performed analyses showed that the biggest changes were definitely occurring in the MA core, i.e. in Lublin, where over the period of 20 studied years, the percentage of arable land decreased from around 50\% to 40\%. Undeniably, smaller changes occurred in municipalities located outside the core. However, the hypothesis that strong pressure of the non-agricultural sector in the city of Lublin would affect the reduction of the share of arable land mainly in municipalities close to the city was not confirmed. In the case of the analysed municipalities, the natural conditions of agricultural activity were of greater importance in the conversion processes of arable land. Larger losses of arable land were recorded in municipalities with the worse farming conditions.

Despite trends in other metropolitan areas (in Poland and abroad), only small changes in the share of built-up land were noted. Only in Lublin, increase in this category was recorded at the level higher than 1 percentage point. Therefore, there is virtually no transfer of land from agriculture to non-agricultural activities.

The research also showed that, in the analysed municipalities, arable land was mainly transformed into grassland. The progressive reduction in the intensity of agricultural activity is typical for the areas of fragmented farmland, and particularly valid in the municipalities with an attractive labour market. The growing share of green land with simultaneous regression of animal production may, however, result from a speculative activity. The owners of agricultural land do not want to sell or lease it, because possession of land at a relatively short distance from the city can bring benefits in the form of a planning rent or a location rent. This phenomenon is not favourable, because 
the agricultural land, especially coupled with good environmental conditions, should be transferred to other farms and not be subject to extensification processes.

We acknowledge the support by the National Science Centre, Poland under project No. 2016/21/D/HS4/00264.

\section{References}

Abrantes P., Fontes I., Gomes E., Rocha J. 2016. Compliance of land cover changes with municipal land use planning: Evidence from the Lisbon metropolitan region (1990-2007). Land Use Policy, 51, 120-134.

Adamczyk J., Bałazy R., Będkowski K., Brach M., Choromański A., Grzegorzewicz T., Kamińska G., Karaszkiewicz W., Konieczny A., Korpetta D., Neroj B., Okła K., Olenderek H., Olenderek T., Pajda A., Pigan M., Rutkowski R., Stankiewicz K., Starzycka J., Strzeliński P., Talarczyk A., Tracz W., Wężyk P., Wiśniewska E., Zawiła-Niedźwiecki T. 2010. Geomatyka w Lasach Państwowych. Część I. Podstawy. CILP, Warszawa, 277-297, 312-319, 393.

Alonso W. 1964. Location and Land Use. Harvard University Press, Cambridge, MA, USA.

Antrop M. 2004. Landscape change and the urbanization process in Europe. Landscape and Urban Planning, 67 (1-4), 9-26.

Bałazy R., Brach M., Bruchwald A., Choromański A., Dmyterko E., Grzegorzewicz T., Kyc P., Łabaj A., Majsterkiewicz K., Neroj B., Okła K., Olenderek H., Olenderek T., Prengel J., Talarczyk A., Wasiak A., Wężyk P., Wiśniewska E., Witosza W., Zajączkowski G. 2013. Geomatyka w Lasach Państwowych. Część II. Poradnik praktyczny. CILP, Warszawa, 390.

Bauer M.E., Yuan F., Sawaya K.E., Loeffelholz B.C. 2003. Multi-temporal landsat image classification and change analysis of land cover in the twin cities (minnesota) metropolitan area. MutiTemp 2003, Second International Workshop on the Analysis of Multi-temporal Remote Sensing Images. July 16-18, Ispra, Italy.

Bochenek Z. 2004. Zastosowanie różnych metod określania zmian pokrycia terenu na obszarach miejskich z wykorzystaniem zdjęć satelitarnych. Archiwum Fotogrametrii, Kartografii i Teledetekcji, 14, 1-13.

Busko M., Szafranska B. 2018. Analysis of Changes in Land Use Patterns Pursuant to the Conversion of Agricultural Land to Non-Agricultural Use in the Context of the Sustainable Development of the Malopolska Region. Sustainability, 10, 136.

Cakir H.I., Khorram S., Nelson S.A.C. 2006. Correspondence analysis for detecting land cover change. Remote Sens. Environ., 102, 306-317.

Ciołkosz A., Poławski Z.F. 2006. Zmiany użytkowania ziemi w Polsce w drugiej połowie XX wieku. Przegląd Geograficzny, 78, 2, 173-190.

Civco D.L., Hurd J.D., Wilson E.H., Song M., Zhang Z. 2002. A comparison of land use and land cover change detection methods. ASPRS-ACSM Annual Conference and FIG XXII Congress.

Chen J., Gong P., He C., Pu R., Shi P. 2003. Land-Use/Land Cover Change Detection Using Improved Change-Vector Analysis. Photogrammetric Engineering \& Remote Sensing, 69, 4, 369-379.

Diogo V., Koomen E., Kuhlman T. 2015. An economic theory-based explanatory model of agricultural land-use patterns: The Netherlands as a case study. Agric. Syst., 139, 1-16.

Esposito P., Patriarca F., Salvati L. 2018. Tertiarization and land use change: The case of Italy. Economic Modelling, 71, 80-86. 
Gellrich M., Zimmermann N.E. 2007. Investigating the regional-scale pattern of agricultural land abandonment in the Swiss mountains: A spatial statistical modelling approach. Landsc. Urban Plan., 79, 65-76.

GUS 2017. Urząd Statystyczny w Warszawie, Warszawa.

Hersperger A.M., Oliveira E., Pagliarin S., Palka G., Verburg P., Bolliger J., Grădinaru S. 2018. Urban land-use change: The role of strategic spatial planning. Glob. Environ. Change, 51, $32-42$.

Kociuba D. 2011. Funkcje metropolitalne Lublina. Studia Miejskie, 4, 267-181.

Krischke M., Niemeyer W., Scherer S. 2000. RapidEye satellite based geo-information system. Acta Astronautica, 46, 307-312.

Krzyk P., Tokarczuk T., Heczko-Hyłowa E., Ziobrowski Z. 2013. Obszary rolne jako element struktury przestrzennej miast. Problemy planistyczne. Instytut Rozwoju Miast, Kraków, 48-69.

Kwoczyńska B., Piech I., Woźniak R. 2018. Analysis of the impact of construction of selected water reservoirs on the surrounding environment made on the basis of satellite data. E3S Web of Conferences 63, 00008, https://doi.org/10.1051/e3sconf/20186300008

Leal Filho W., Mandel M., Al-Amin A.Q., Feher A., Chiappetta Jabbour C.J. 2017. An assessment of the causes and consequences of agricultural land abandonment in Europe. International Journal of Sustainable Development \& World Ecology, 4 (6), 554-560.

Li X., Yeh A.G.O. 1998. Principal component analysis of stacked multi-temporal images for the monitoring of rapid urban expansion in the Pearl River Delta. Int. J. Remote Sens., 19 (8), 1501-1518.

Loveland T.R., Dwyer J.L. 2012. LANDSAT: Building a strong future. Remote Sens. Environ., 122, 22-29.

Lovell S.T. 2010. Multifunctional Urban Agriculture for Sustainable Land Use Planning in the United States. Sustainability, 2, 2499-2522.

Lorens P., Martyniuk-Pęczek J. 2010. Zarządzanie rozwojem przestrzennym miast. Wydawnictwo Urbanista, Gdańsk, 16-42.

Lu D., Mausel P., Brondízio E., Moran E. 2004. Change detection techniques. Int. J. Remote Sens., 25, 12, 2365-2407.

Mace A. 2018. The Metropolitan Green Belt, changing an institution. Progress in Planning, 121, $1-28$.

Markham B.L., Helder D.L. 2012. Forty-year calibrated record of earth-reflected radiance from LANDSAT: A review. Remote Sens. Environ., 122, 30-40.

Mazzocchi C., Sali G., Corsi S. 2013. Land use conversion in metropolitan areas and the permanence of agriculture: Sensitivity Index of Agricultural Land (SIAL), a tool for territorial analysis. Land Use Policy, 35, 155-162.

Michałowska K., Głowienka-Mikrut E. 2010. Wieloczasowe dane obrazowe w badaniu zmian pokrycia terenu. Archiwum Fotogrametrii, Kartografii i Teledetekcji, 21, 281-289.

Musiał W., Wojewodzic T. 2014. Bariery przemian agrarnych w rolnictwie polskim - poszukiwanie rozwiązań innowacyjnych. [W:] Problemy rozwoju rolnictwa i gospodarki żywnościowej w pierwszej dekadzie członkostwa Polski w Unii Europejskiej, red. A. Czyżewski, B. Klepacki. Polskie Towarzystwo Ekonomiczne, Warszawa, 91-109.

Niedzielko J., Lewiński S. 2012. Detekcja zmian pokrycia terenu na zdjęciach satelitarnych Landsat - porównanie trzech metod. Teledetekcja Środowiska, Warszawa.

Oliveira Duarte D., Zanetti J., Gripp J., Graças Medeiros N. 2016. Comparison of supervised classification methods of Maximum Likelihood image, Minimum Distance, Parallelepiped and Neural network in images of Unmanned Air Vehicle (UAV) in Viçosa-MG, Civil Engineering Department, Federal University of Viçosa (UFV), Campos do Jordao, 30.11.2016. 
Piorr A., Ravetz J., Tosics I. 2011. Peri-Urbanisation in Europe: Towards European Policies to Sustain Urban-Rural Futures. Forest \& Landscape, University of Copenhagen: Copenhagen, Denmark, 30-42.

Pölling B., Sroka W., Mergenthaler M. 2017. Success of urban farming's city-adjustments and business models. Findings from a survey among farmers in Ruhr Metropolis, Germany. Land Use Policy, 69, 372-385.

Prakasam C. 2010. Land use and land cover change detection through remote sensing approach: A case study of Kodaikanal taluk, Tamilnadu. International Journal of Geomatics and Geosciences, 1, 2, 150-158.

Price B., Kienast F., Seidl I., Ginzler C., Verburg P.H., Bolliger J. 2015. Future landscapes of Switzerland: Risk areas for urbanisation and land abandonment. Applied Geography, 57, $32-41$.

Queiroz C., Beilin R., Folke C., Lindborg R. 2014. Farmland abandonment: threat or opportunity for biodiversity conservation? A global review. Front. Ecol. Environ., 12 (5), 288-296.

Sandau R., Brieß K., D’Errico M. 2010. Small satellites for global coverage: Potential limits. ISPRS J. Photogramm. Remote Sens., 65, 492-504.

Satoła Ł., Wojewodzic T., Sroka W. 2018. Barriers to exit encountered by small farms in light of the theory of new institutional economics. Agric. Econ. - Czech, 64 (6), 277-290.

SRGK 2016. Strategia rozwoju gminy Konopnica na lata 2016-2022. Urząd Gminy Konopnica. Konopnica, Poland. http://www.konopnica.eu/wp-content/uploads/2016/06/UGK_Strategia_Rozwoju_10_02_2016.pdf (accessed: 2 September 2018).

SRGM 2016. Strategia rozwoju gminy Mełgiew na lata 2016-2022. Urząd Gminy Mełgiew. Mełgiew, Poland. http://www.melgiew.pl/files/files/dokumenty_interesanta/Gmina_Melgiew_-_Strategia_Rozwoju_Gminy_-_FINA\%C5\%81.pdf (accessed: 2 September 2018).

SRGW 2009. Strategia rozwoju Gminy Wólka na lata 2007-2020. Urząd Gminy Wólka. Wólka, Poland. http://bip.wolka.pl/wiadomosci/638/wiadomosc/104266/uchwala_nr_xlvi30809_ rady_gminy_wolka_z_dnia_30_listopada_2009_r. (accessed: 2 September 2018).

Sroka W., Płonka A., Krzyk P. 2017. Exploring the factors of farmland abandonment - a case study of the chosen Polish metropolitan areas. Roczniki Naukowe Stowarzyszenia Ekonomistów Rolnictwa i Agrobiznesu, 19 (4), 187-194.

Sroka W., Mikolajczyk J., Wojewodzic T., Kwoczynska B. 2018. Agricultural Land vs. Urbanisation in Chosen Polish Metropolitan Areas: A Spatial Analysis Based on Regression Trees. Sustainability, 10 (3), 837.

Sroka W. 2018. Conversion of agricultural land to non-agricultural purposes in selected Polish metropolitan areas. Acta Sci. Pol., ser. Oeconomia, 17 (2), 97-107, DOI: 10.22630/ ASPE.2018.17.2.25

Terres J.M., Scacchiafichi L.N., Wania A., Ambar M., Anguiano E., Buckwell A., Strijker D. 2015. Farmland abandonment in Europe: Identification of drivers and indicators, and development of a composite indicator of risk. Land Use Policy, 49, 20-34.

Urząd Statystyczny w Krakowie 2016. Krakowski Obszar Metropolitalny w latach 2011-2015. Kraków.

Ustaoglu E., Castillo C.P., Jacobs-Crisioni C., Lavalle C. 2016. Economic evaluation of agricultural land to assess land use changes. Land Use Policy, 56, 125-146.

Verburg P.H., van de Steeg J., Veldkamp A., Willemen L. 2009. From land cover change to land function dynamics: A major challenge to improve land characterization. J. Environ. Manage., 90, 1327-1335.

Wästfelt A., Zhang Q. 2016. Reclaiming localisation for revitalising agriculture: A case study of peri-urban agricultural change in Gothenburg, Sweden. J. Rural Stud., 47, 172-185. 
Wężyk P., Wójtowicz-Nowakowska A., Pierzchalski M., Mlost J., Szafrańska B. 2013. Mapa zmian pokrycia terenu Małopolski 1986-2011 wykonana w oparciu o klasyfikację obiektową obrazów satelitarnych LANDSAT oraz RapidEye. Archiwum Fotogrametrii, Kartografii i Teledetekcji, 25, 273-284.

Wężyk P., Cisło-Lesicka U., Bajorek-Zydroń K., de Kok R. 2016. Kartowanie pokrycia i użytkowania terenu okolic Krakowa z wykorzystaniem klasyfikacji OBIA oraz danych teledetekcyjnych i GIS. Pokrycie terenu i przewietrzanie Krakowa. Konferencja, Kraków 20.10.2016.

Witek T. 1994. Waloryzacja rolniczej przestrzeni produkcyjnej Polski według gmin. IUNG, Puławy, 166-248.

Wojewodzic T. 2012. Divestments in the process of developing off-farm economic activity by farmers. Acta Sci. Pol., ser. Oeconomia, 3, 77-85.

Wojewodzic T. 2017. Procesy dywestycji i dezagraryzacji w rolnictwie na obszarach o rozdrobnionej strukturze agrarnej. Zeszyty Naukowe Uniwersytetu Rolniczego im. H. Kołłątaja w Krakowie, 535, ser. Rozprawy, 412, 287.

Wulder M.A., Masek J.G., Cohen W.B., Loveland T.R., Woodcock C.E. 2012. Opening the archive: How free data has enabled the science and monitoring promise of LANDSAT. Remote Sens. Environ., 122, 2-10.

Xie H., Wang P., Yao G. 2014. Exploring the dynamic mechanisms of farmland abandonment based on a spatially explicit economic model for environmental sustainability: A case study in Jiangxi Province, China. Sustainability, 6, 1260-1282.

Zasada I. 2011. Multifunctional peri-urban agriculture. A review of societal demands and the provision of goods and services by farming. Land Use Policy, 28, 639-648.

Dr inż. Bogusława Kwoczyńska

Uniwersytet Rolniczy w Krakowie

Katedra Geodezji Rolnej, Katastru i Fotogrametrii

ul. Balicka 253a, 30-149 Kraków

e-mail: rmkwoczy@cyf-kr.edu.pl

ORCID: 0000-0001-7230-5397

Dr Wojciech Sroka

Uniwersytet Rolniczy w Krakowie

Katedra Ekonomii i Gospodarki Żywnościowej

al. Mickiewicza 21, 31-120 Kraków

e-mail:w.sroka@ur.krakow.pl

ORCID: 0000-0002-4255-3741

Mgr inż. Kamila Sikora

Geoproces Sp. z o.o.

41-500 Chorzów, ul. Pudlerska 21

e-mail: s.kamila94@interia.pl 